\title{
The role of the subtropical jet in deficient winter precipitation across the mid- Holocene Indus basin
}

Article

Supplemental Material

Hunt, K. M. R. and Turner, A. G. (2019) The role of the subtropical jet in deficient winter precipitation across the midHolocene Indus basin. Geophysical Research Letters, 46 (10). pp. 5452-5459. ISSN 0094-8276 doi:

https://doi.org/10.1029/2019GL081920 Available at https://centaur.reading.ac.uk/83142/

It is advisable to refer to the publisher's version if you intend to cite from the work. See Guidance on citing.

To link to this article DOI: http://dx.doi.org/10.1029/2019GL081920

Publisher: American Geophysical Union

All outputs in CentAUR are protected by Intellectual Property Rights law, including copyright law. Copyright and IPR is retained by the creators or other copyright holders. Terms and conditions for use of this material are defined in the End User Agreement.

www.reading.ac.uk/centaur 
Central Archive at the University of Reading

Reading's research outputs online 


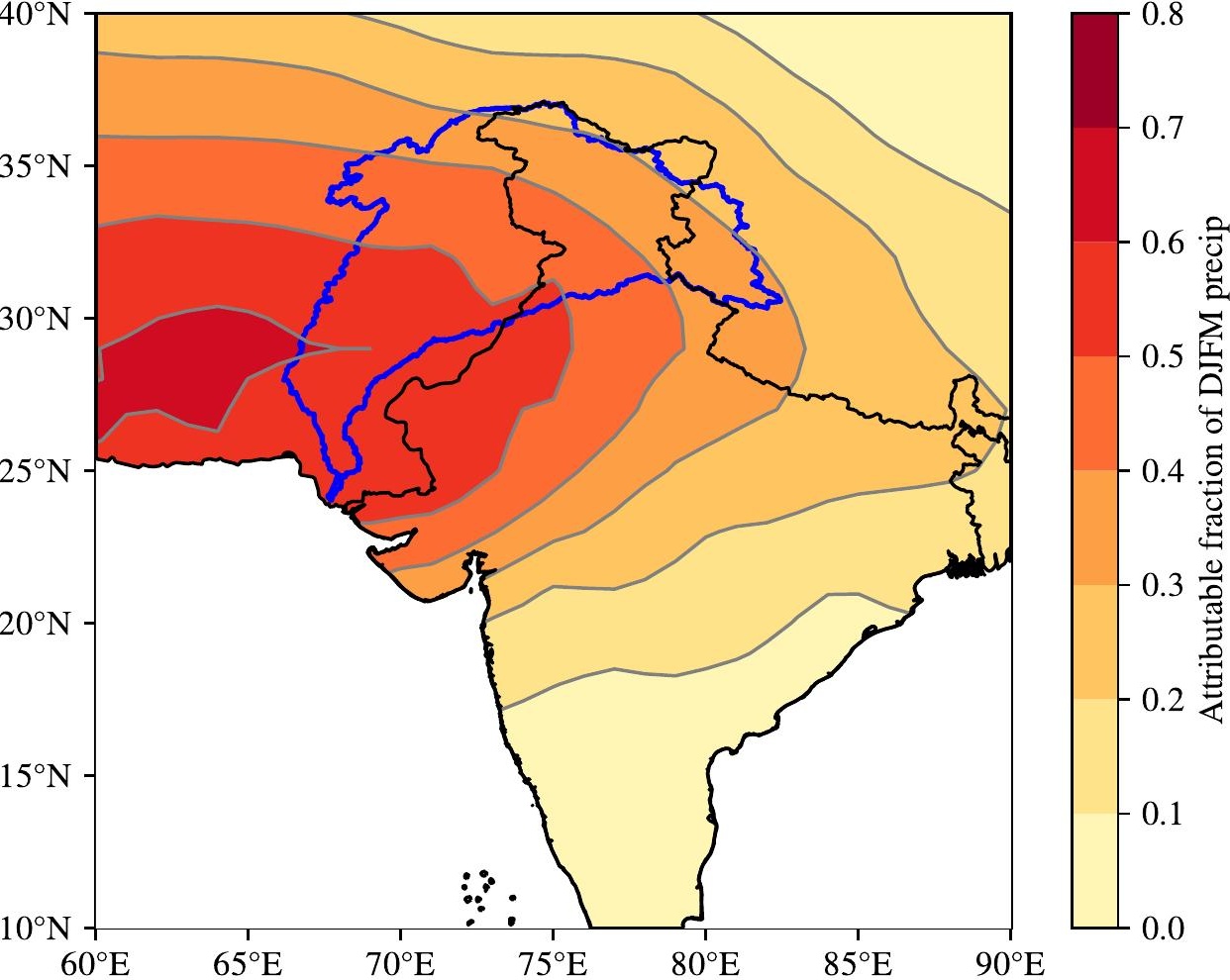

